\title{
LANGUAGE AND VISUOMOTOR DEVELOPMENT IN CHILDREN AGED 1-3 YEARS IN SUBDISTRICT BULAK, SURABAYA
}

\author{
Dwi Susanti \\ Department of Public Health and Preventive Medicine, \\ Faculty of Medicine, Universitas Airlangga
}

\begin{abstract}
ABSTRAK
Kegiatan pemantauan perkembangan anak usia batita penting untuk dilakukan karena masa ini merupakan periode kritis perkembangan. Tujuan penelitian ini untuk mengetahui prevalensi penyimpangan perkembangan anak usia 1-3 tahun di wilayah Kecamatan Bulak, Surabaya. Penelitian ini merupakan penelitian deskriptif cross-sectional. Subjek penelitian sebanyak 98 anak usia 1-3 tahun yang didapatkan secara cluster random sampling. Pemeriksaan perkembangan dilakukan menggunakan alat skrining perkembangan skala Capute (CAT-CLAMS test). Hasilnya, nilai perkembangan total (FSDQ) rata-rata sebesar 97,88 $\pm 12,26$, nilai perkembangan visuomotor (CAT) rata-rata 92,58 $\pm 16,10$ sedangkan nilai perkembangan bahasa (CLAMS) rata-rata 102,67 \pm 13,63. Berdasarkan skor FSDQ, 84,2\% anak memiliki skor >85 (normal). Sisanya 2,1\% termasuk kategori developmental delay (skor < 75) dan 13,7\% memiliki skor 75-85 (suspek). Jadi, prevalensi penyimpangan perkembangan anak usia 1-3 tahun di Kecamatan Bulak sekitar 15,8\%. (FMI 2016;52:94-97)
\end{abstract}

Kata kunci: prevalensi, penyimpangan perkembangan, anak usia 1-3 tahun, skala Capute (CAT-CALMS test)

\begin{abstract}
Monitoring childhood activities especially for toddlers is important to review because this period is a golden period for chilhood development. The aim of this research to review determine the prevalence of irregularities childhood development for toddler that aged 1-3 years in District of Bulak, Surabaya. This research is a descriptive cross-sectional study. The study subjects were 98 children aged 1-3 Years that obtained by cluster random sampling. The examination conducted using a screening tool prospective development of the Capute scale (CAT test - SHELL). The result, total of value development (FSDQ) average of 97.88 \pm 12.26 , visuomotor development value (CAT) average 92.58 \pm 16.10 while value language development (CLAMS) average $102.67 \pm 13.63$. Based on FSDQ score, $84.2 \%$ of child had $>85$ (normal). The remaining $2.1 \%$ including developmental disorders had $<75$ and $13.7 \%$ had score 75-85 (suspected). So, the prevalence of irregularities childhood development for toddlers that aged 1-3 years in District of Bulak around 15.8\%. (FMI 2016;52:94-97)
\end{abstract}

Keywords: prevalence, irregularities childhood development, toddler aged 1-3 years, Capute scale (CAT-CALMS) test

Correspondence: Dwi Susanti, Department of Public Health and Preventive Medicine, Faculty of Medicine, Universitas Airlangga, Jalan Prof dr Moestopo 47, Surabaya 60131, Indonesia.

\section{INTRODUCTION}

At the age Toddler brain development occurs very rapidly and the structure of the brain is very sensitive to the experience or stimulation (Robson 2001). Development inspection activities should be conducted in this golden period, because if developmental disorders can be detected early and immediate early intervention, the result will be much better because of the structure of a child's brain is still very responsive to stimulation provided.

Subdistrict Bulak is located in the coastal region Kenjeran Beach. Kenjeran Beach Surabaya is the eastern coastal region of East Java, which becomes the mouth of the rivers in urban areas. There are many large companies in Surabaya dump wastes in rivers that eventually flow into Kenjeran Beach. This allows for heavy metal pollution (one of which is the lead in Kenjeran Beach waters (Arief 2005). The concentration of lead in the mud in the waters of Surabaya in 2000 range from $7.334 \mathrm{ppm}$, while the content in sea water ranged $0,004-1,094 \mathrm{mg} / \mathrm{L}$, depending on the location of the sample, the closer to the waterfront the concentration was higher (Arief 2005). Based on the decision of the State Ministry of Environment number 51 of 2004 on the quality standard of sea water for marine life was determined that lead levels of sea water should not exceed 0,008 mg/L (Ministry of State 2004). Heavy metal pollution that allegedly occurred in Kenjeran Beach is certainly feared could disrupt the growth process of children, especially toddlers who lived in the vicinity. This study aims to determine the 
prevalence of developmental disorders of children aged 1-3 years in the District of Bulak, Surabaya.

\section{MATERIALS AND METHODS}

This study is a cross-sectional descriptive study. Subjects were children aged 12-35 months, living in the District of Bulak, and parents willing to sign informedconsent. Children who are known to suffer from congenital abnormalities such as Down's syndrome and Hidrocephalus excluded. Selection of research subject was done by cluster random sampling. This research was conducted at the Regional Public Health Center Kenjeran the Month October-December 2012. The working area of Puskesmas Kenjeran located in District of Bulak. There are 29 posyandu in the working area Kenjeran health centers. Eight posyandu were randomly selected in five villages in the District of Bulak. Kids Toddlers who come to selected Posyandu, chosen at random and used as research subjects. This research obtains 95 research subjects.

Variable research is the development of language, visuomotor development, and development of the total. Development checks are conducted using a screening tool to develop a scale Capute (CAT-clams test). Capute scale is one of the developmental screening tools that assess the development of the components of language and visual-motor aspects of the toddler. Several studies conducted in high-risk populations concluded that Capute scale screening tools have high validity of the standard screening tool Bayley Scales of Infant Development or often referred to as the Bayley scale (Hoon et al 1993).

\section{RESULTS}

In this study, the minimum age of the sample was 12 months, and a maximum of 35 months, with a median of 24 months. The characteristic feature of the sample which includes the distribution of age, sex, history of breastfeeding, nutritional status, and economic status of the family can be seen in Table 1 .
Table 1. Distribution of age, sex, history of breastfeeding and nutritional status

\begin{tabular}{lrr}
\hline \multicolumn{1}{c}{ Categories } & $\mathrm{n}$ & $\%$ \\
\hline Age & & \\
Age 12-17 months & 22 & 23.2 \\
Age 18-23 months & 25 & 26.3 \\
Age 24-29 months & 25 & 26.3 \\
Age 30-35 months & 23 & 24.2 \\
Sex & & \\
Male & 39 & 41.1 \\
Female & 56 & 58.9 \\
Breastfeeding history & & \\
$\quad$ Not exclusive & 80 & 84.2 \\
$\quad$ Exclusive & 15 & 15.8 \\
Nutritional status (BB/TB) & & \\
$\quad$ Very lean & 11 & 11.6 \\
$\quad$ Lean & 4 & 4.2 \\
$\quad$ Normal & 76 & 80.0 \\
$\quad$ Obesity & 4 & 4.2 \\
Family economic status & & \\
$\quad$ Lower & 17 & 18.3 \\
$\quad$ Upper & 76 & 81.7 \\
\hline
\end{tabular}

Toddler Table 1 shows the distribution by age and sex in each category are almost the same. Toddlers history were exclusively breastfed in the District of Bulak only about $15.8 \%$. Toddlers in District of Bulak were categorized as very thin reached $11.6 \%$. Approximately $18.3 \%$ of toddlers come down economy class.

Table 2 shows that the total development scores (FSDQ), language development scores (clams-DQ) and visual development of the motor score (CAT-DQ) toddlers in District of Bulak, on average above 90.

Score total development (FSDQ) can be interpreted into three categories, namely Normal development when FSDQ score $>85$, when the score FSDQ Suspect is in the range 75-85, and Developmental Delay when FSDQ score $<75$ (Dhamayanti \& Herlina 2009). The number and percentage of samples that fall into each category of development can be seen in Table 3 .

Table 2. Distribution of cognitive developmental scale score capute

\begin{tabular}{lcccc}
\hline \multicolumn{1}{c}{ FSDQ } & $\mathrm{n}$ & $\begin{array}{c}\text { FSDQ } \\
\mathrm{x} \pm \mathrm{sd}\end{array}$ & $\begin{array}{c}\text { CLAMS-DQ } \\
\mathrm{x} \pm \mathrm{sd}\end{array}$ & $\begin{array}{c}\text { CAT-DQ } \\
\mathrm{x} \pm \mathrm{sd}\end{array}$ \\
\hline Kelurahan Bulak & 26 & $97.62 \pm 14.21$ & $92.38 \pm 19.39$ & $102.31 \pm 13.43$ \\
Kelurahan Kedung cowek & 15 & $94.6 \pm 8.52$ & $91.67 \pm 8.01$ & $97.13 \pm 14.99$ \\
Kelurahan Kenjeran & 30 & $99.23 \pm 12.65$ & $93.27 \pm 17.79$ & $104.73 \pm 14.01$ \\
Kelurahan Kompleks Kenjeran & 12 & $98.58 \pm 12.65$ & $92.42 \pm 15.08$ & $104.17 \pm 12.49$ \\
Kelurahan Sukolilo & 12 & $98.5 \pm 11.4$ & $92.58 \pm 14.63$ & $103.75 \pm 12.65$ \\
Total ( Kecamatan Bulak) & 95 & $97.88 \pm 12.26$ & $92.58 \pm 16.10$ & $102.67 \pm 13.63$ \\
\hline
\end{tabular}


Table 3. Distribution of categories of cognitive development of toddlers in District of Bulak based on the total development scores (FSDQ)

\begin{tabular}{lcc}
\hline $\begin{array}{l}\text { Cognitive development of } \\
\text { children under three years } \\
\text { based on FSDQ scores }\end{array}$ & $\mathrm{n}$ & $\%$ \\
\hline Developmental delay & 2 & 2.11 \\
Suspect & 13 & 13.68 \\
Normal & 80 & 84.21 \\
Total & 95 & 100 \\
\hline Note: $\mathrm{n}=$ number of samples & & \\
\end{tabular}

\section{DISCUSSION}

Characteristics of the sample in this study can be seen in Table 1. Based on data in Table 1, history Toddlers are exclusively breastfed in the District of Bulak only about $15.8 \%$. Was significantly lower (analysis with a onesample proportion test $p$ value $=0.0004$ ) than the scope of exclusive breastfeeding in East Java based Reports Health Profile of East Java province in 2011 amounted to $61.52 \%$ (Health Office 2012), and below target set by the Department of Health of the Republic of Indonesia through community nutrition programs increase by $80 \%$ (Fikawati \& Syafiq 2010). Toddlers in District of Bulak were categorized as very thin reached $11.6 \%$, higher and statistically significant (one-sample analysis of the proportion of test $\mathrm{p}$ value $=0.0000$ ) compared with the incidence of malnutrition in East Java in 2011 of 1, 16\% (Health Office 2012).

Family income toddlers in District of Bulak average Rp. 579479 per capita per month, at least Rp. 35,000 per capita per month, maximum Rp. 2.3333 million per capita per month. Based on the Minimum Wage Cities (UMK) Surabaya in 2012 amounted to Rp. 314250 per capita per month (Decree of the Governor of East Java 2011), the family economic status toddler divided into lower economic status when the family income $<$ Rp.314.250/capita/month, economic status on if the family income $>$ Rp. 314250 . Family toddlers who entered under the economic class reached $30.11 \%$.

Toddlers in villages Kedungcowek had an average score of total development (FSDQ), language development scores (clams-DQ), and the visual development of the motor score (CAT-DQ) is lowest. When viewed from the location, the village is a village Kedungcowek directly adjacent to the beach. People living near Kenjeran waters, especially fishermen and their families consume fish 99.11 gram/day (Sudarmadji et al 2004) or 22 grams of protein fish/day, higher than the average national fish protein intake of 7.65 grams/capita/day in
2004 and 8.02 grams/per capita/day in 2011 (Statistics Central Bureau 2011). The greater the consumption of marine fish suspected heavy metal contaminated lead the greater the accumulation of heavy metals of lead in the body. If this occurs in children, the accumulation of lead in the body can interfere with the process of growth and development.

Based on the results of research by a team of DIY ADKL 2000 in Yogyakarta found that lead contamination in children can result in decreased IQ and no effect on weight gain as well as the emotional state of the child such as frequent crying and fussing (Sutomo 2001). Lead contamination in children also interfere with the metabolism of heme that can cause anemia, nervous system disorders, thereby reducing the intelligence, adversely affect bone metabolism, vitamin $\mathrm{D}$ and calcium can cause bone growth (Skerfving \& Bergdahl 2005). Several studies have shown that exposure to lead can adversely affect children's cognitive development and behavior (Mazumdar et al 2011, Pocock et al 1994, Roman-Torres et al 2007, Apostoli et al 2005).

At $2.11 \%$ toddlers in District of Bulak indicated experiencing developmental delay with FSDQ score $<75$ and $13.68 \%$ had a score of $75-85$ (suspected). But as the scale Capute is one screening tool, children who enter the category Developmental delay and suspect still must be checked by using the tool checks the development of more specific and diagnostic to confirm the diagnosis development.

\section{CONCLUSION}

Total development value (FSDQ) toddlers in District of Bulak average of $97.88 \pm 12.26$. The prevalence of developmental disorders of children aged 1-3 years based on the results of the examination using a scale Capute Bulak in District 15.8\%.

\section{REFERENCES}

Apostoli P, Telisman S, Sager PR (2005). Reproductive and developmental toxicity of metals. In: Nordberg GF, Fowler BA, Nordberg M, Friberg L (eds). Handbook on The Toxicology of Metal, 3rd ed, Copenhagen, European Environment Agency, p 236238

Arief M (2005). Pengaruh konsumsi ikan laut dan kerang terhadap kadar $\mathrm{Pb}$ darah manusia, studi kasus di kelurahan Sukolilo, Kenjeran, Surabaya. Jurnal Perikanan VII, 108- 114 
Decree of the Governor of East Java (2011). Peraturan Gubernur Jawa Timur No 81 Tahun 2011 Tentang Upah Minimum Kabupaten/Kota Di Jawa Timur Tahun 2012, Surabaya

Dhamayanti M and Herlina M (2009). Skrining gangguan kognitif dan bahasa dengan menggunakan capute scales (cognitive adaptive test/clinical linguistic \& auditory milestone scale-cat/clams). Sari Pediatri 11, 189-198

Fikawati S and Syafiq A (2010). Kajian implementasi dan kebijakan ASI eksklusif dan inisiasi menyusu dini di Indonesia. Makara Kesehatan 14, 17-24

Health Office, Province of East Java (2012). Profil Kesehatan Provinsi Jawa Timur Tahun 2011, Surabaya

Hoon AH, Pulsifer MB, Gopalan R, Palmer FB, Capute AJ (1993). Clinical adaptive test/clinical linguistic auditory milestone scale in early cognitive assessment. The Journal of Pediatrics 123, S1-S8

Mazumdar M, Bellinger DC, Gregas M, Abanilla K, Bacic J, Needleman HL (2011). Low-level environmental lead exposure in childhood and adult intellectual function: a follow up study. Environmental Health journal 10, 1- 7

Pocock SJ, Smith M, Baghurst P (1994). Environmental lead and children's intelligence: a systematic review of the epidemiological evidence. BMJ 309, 1189-1197
Robson AL (2001). Critical/sensitive periods. In: Salkind NJ (ed). Child Development, New York, MacMillan Reference

Roma-Torres J, Silva S, Costa C, Coelho P, Henriques MA, Teixeira JP, Mayan O (2007). Lead exposure of children and newborns in Porto, Portugal. International Journal Hygiene and Environmental Health 210, 411-414

Skerfving S and Bergdahl IA (2005). Lead. In: Nordberg GF, Fowler BA, Nordberg M, Friberg L (eds). Handbook on The Toxycology of Metal, 3rd ed, Copenhagen, European environment agency, p 599635

State Ministry of Environment (2004). Keputusan Menteri Negara Lingkungan Hidup No 51 Tahun 2004 Tentang Baku Mutu Air Laut Jakarta

Statistics Central Bureau (2011). Rata- rata Konsumsi Kalori (gram) per Kapita Menurut Kelompok Makanan 1999, 2002- 2011, Jakarta

Sudarmadji, Sutomo AH, Suwarni A (2004). Konsumsi ikan laut, kadar merkuri dalam rambut, dan kesehatan nelayan di pantai Kenjeran, Surabaya. Jurnal Manusia dan Lingkungan IX, 134-142

Sutomo AH (2001). Dampak pencemaran timbal terhadap tumbuh kembang anak di kota Yogyakarta tahun 2000. Jurnal Energi XIII, 43-52 